\title{
Effects of Enzymatically Synthesized Glycogen and Exercise on Abdominal Fat Accumulation in High-Fat Diet-Fed Mice
}

\author{
Shohei TAMURA, Kazuhisa HondA*, Ryoji MorinagA, \\ Takaoki SANEYASU and Hiroshi KAMISOYAMA \\ Graduate School of Agricultural Science, Kobe University, Kobe 657-8501, Japan \\ (Received May 8, 2017)
}

\begin{abstract}
Summary The combination of diet and exercise is the first choice for the treatment of obesity and metabolic syndrome. We previously reported that enzymatically synthesized glycogen (ESG) suppresses abdominal fat accumulation in obese rats. However, the effect of the combination of ESG and exercise on abdominal fat accumulation has not yet been investigated. Our goal in this study was therefore to evaluate the effects of dietary ESG and its combination with exercise on abdominal fat accumulation in high-fat diet (HFD)-fed mice. Male ICR mice were assigned to four groups: HFD, HFD containing 20\% ESG, HFD with exercise, HFD containing 20\% ESG with exercise. Treadmill exercise was performed for $3 \mathrm{wk}(25 \mathrm{~m} /$ $\mathrm{min}, 30 \mathrm{~min} / \mathrm{d}, 3 \mathrm{~d} / \mathrm{wk}$ ) after 5-d adaption to running at that speed. Both ESG and exercise significantly reduced the weights of abdominal adipose tissues. In addition, the combination of ESG and exercise significantly suppressed abdominal fat accumulation, suggesting that ESG and exercise showed an additive effect. Exercise significantly increased the mRNA levels of lipid metabolism-related genes such as lipoprotein lipase, peroxisome proliferator-activated receptor delta; factor-delta $(\operatorname{PPAR} \delta)$, carnitin palmitoyltransferase b, adipose triglyceride lipase (ATGL), and uncoupling protein-3 in the gastrocnemius muscle. On the other hand, dietary ESG significantly decreased the mRNA levels of PPAR $\delta$ and ATGL in the gastrocnemius muscle. These results suggest that the combined treatment of ESG and exercise effectively suppresses abdominal fat accumulation in HFD-fed mice by different mechanisms.
\end{abstract}

Key Words exercise, glycogen, fat, mice

Obesity is an established risk factor for several diseases, such as cardiovascular disease (CVD) (1) and type 2 diabetes (T2D) (2). In addition, overall mortality was lowest in adults with a body mass index (BMI) of about $22.5-25 \mathrm{~kg} / \mathrm{m}^{2}$ in both sexes and at all ages, after exclusion of early follow-up and adjustment for smoking status, and above this range, each $5 \mathrm{~kg} / \mathrm{m}^{2}$ higher BMI was associated with about 30\% higher all-cause mortality (1). However, the prevalence of overweight and obese people has globally increased in the last few decades (3-5). For example, the number of individuals with a BMI of $25 \mathrm{~kg} / \mathrm{m}^{2}$ or greater, defined as overweight or obese by the World Health Organization (WHO) guidelines, increased from 857 million in 1980 , to 2.1 billion in 2013 (5). Therefore, an urgent need for the effective prevention and cure of obesity has been growing.

Visceral adipose tissue is more strongly associated with metabolic syndrome, a multiplex risk factor for atherosclerotic CVD and T2D (6), than subcutaneous adipose tissue $(7,8)$. For example, a man with a normal BMI and central obesity, measured by waist-to-hip ratio, had greater total mortality risk than one with similar BMI but no central obesity, and this man had twice the mortality risk of participants who were overweight or obese according to BMI only (9). Both obesity and diabe-

\footnotetext{
*To whom correspondence should be addressed.
}

E-mail: honda@tiger.kobe-u.ac.jp tes are highly prevalent in Westernized countries, where dietary fat accounts for almost $40 \%$ of ingested calories, suggesting that excessive intake of dietary fat is a salient contributor to the development of these diseases (10). Therefore, the suppression of visceral fat accumulation in high-fat diet (HFD)-fed animals has been investigated.

Recently, an in vitro synthesis method for enzymatically synthesized glycogen (ESG) from starch using isoamylase (EC 3.2.1.68), branching enzyme (EC 2.4.1.18), and amylomaltase (EC 2.4.1.25) was developed (11). ESG closely resembles natural source glycogen in structural parameters, physicochemical properties and molecular shape (11-13) and shows various biological properties, including immunostimulating activity (14), indigestibility (15) and intestinal environment improving effect (15). Moreover, the addition of ESG in a HFD resulted in significant decreases in total body fat mass as well as visceral fat mass in rats (16). Dietary ESG significantly increased the amount of lipid in the feces in rats (16). We previously showed that about $20 \%$ of ingested ESG acts as a dietary fiber (15), and dietary fiber was reported to increase the amount of fecal lipid $(17,18)$. Because the cecal weight and content were increased after ESG consumption, ESG likely also acted as a dietary fiber. These findings suggest that ESG may suppress body fat accumulation by decreasing lipid absorption.

On the other hand, the mRNA levels of hepatic lipid metabolism-related genes were not changed by ESG 
(16). We also confirmed that dietary ESG affected neither the mRNA levels of hepatic lipid metabolism-related enzymes nor the mRNA levels of UCP-1 or the protein levels of eNOS in the brown adipose tissue in HFDinduced obese mice, although the weight of abdominal fat was significantly decreased (unpublished data). It is therefore likely that ESG shows anti-obesity action without affecting lipid metabolism in the liver and brown adipose tissue.

The combination of diet and exercise is the first choice for the treatment of obesity and metabolic syndrome (19-21). Therefore, the combination of ESG and exercise may effectively reduce body fat mass. In this study, we aimed to propose a novel approach for the prevention of obesity, and evaluated the effect of the combination of ESG and exercise on abdominal fat accumulation in HFD-fed mice.

\section{MATERIALS AND METHODS}

Animals and diets. Male ICR mice, $5 \mathrm{wk}$ old, were purchased from Japan SLC, Inc. (Shizuoka, Japan), and
Table 1. Composition of experimental diets (\%).

\begin{tabular}{lcc}
\hline & Control & ESG \\
\hline Casein & 25.8 & 25.8 \\
L-Cystine & 0.39 & 0.39 \\
Maltodextrin & 16.2 & 0 \\
Cellulose & 6.5 & 2.6 \\
ESG & 0 & 20 \\
Sucrose & 8.9 & 8.9 \\
Soybean oil & 3.2 & 3.2 \\
Lard & 31.7 & 31.7 \\
Potassium citrate & 2.1 & 2.1 \\
Dicalcium phosphate & 1.7 & 1.7 \\
Calcium carbonate & 0.71 & 0.71 \\
Mineral mixture ${ }^{2}$ & 1.3 & 1.3 \\
Vitamin mixture & 1.3 & 1.3 \\
Choline bitartrate & 0.26 & 0.26 \\
\hline Energy (kcal/100 g) & 524 & 526 \\
\hline \multicolumn{1}{c}{ AIN-93 mineral mixture (Japan } & SLC, Inc., & Shizuoka, \\
\multicolumn{2}{l}{ Japan). } &
\end{tabular}

Table 2. Primer sequences used for real-time PCR analysis.

\begin{tabular}{|c|c|c|c|}
\hline Target gene & & Primer sequences & GenBank accession No. \\
\hline \multirow[t]{2}{*}{ RPS17 } & Forward & 5'-CCG GGT CAT CAT CGA GAA GT-3' & NM_009092 \\
\hline & Reverse & 5'-GCG CTT GTT GGT GTG GAA GT-3' & \\
\hline \multirow[t]{2}{*}{ ATGL } & Forward & 5'-CCT CAG GAC AGC TCC ACC AA-3' & NM_001163689 \\
\hline & Reverse & 5'-TTG AAC TGC ATG CTG GTG TTG-3' & \\
\hline \multirow[t]{2}{*}{ HSL } & Forward & 5'-CTC CTA TGA CCT ACG GGA AGG A-3' & NM_001039507 \\
\hline & Reverse & 5'-TCA GAT TTT GCC AGG CTG TTG-3' & \\
\hline \multirow[t]{2}{*}{ LPL } & Forward & 5'-GAT GGA CGG TAA CGC GAA TG-3' & NM_0098509 \\
\hline & Reverse & 5'-TAC AGG GCG GCC ACA AGT-3' & \\
\hline \multirow[t]{2}{*}{$\operatorname{PPAR} \gamma$} & Forward & 5'-GCC CAC CAA CTT CGG AAT C-3' & NM_011146 \\
\hline & Reverse & 5'-TGC GAG TGG TCT TCC ATC AC-3' & \\
\hline \multirow[t]{2}{*}{$\operatorname{PPAR} \delta$} & Forward & 5'-GCC ACA ACG CAC CCT TTG-3' & NM_011145 \\
\hline & Reverse & 5'-CCT TCT CTG CCT GCC ACA GT-3' & \\
\hline \multirow[t]{2}{*}{ CPT1b } & Forward & 5'-GTG CAA GCA GCC CGT CTA G-3' & NM_009948 \\
\hline & Reverse & 5'-TTG CGG CGA TAC ATG ATC AT-3' & \\
\hline \multirow[t]{2}{*}{$\mathrm{LCAD}$} & Forward & 5'-GGC TTG CTT GGC ATC AAC A-3' & NM_007381 \\
\hline & Reverse & 5'-AGA GCA AGT CCC CAC CAA TG-3' & \\
\hline \multirow[t]{2}{*}{ UCP-3 } & Forward & 5'-TTT TGC GGA CCT CCT CAC TT-3' & NM_009464 \\
\hline & Reverse & 5'-TGG ATC TGC AGA CGC ACC TT-3' & \\
\hline \multirow[t]{2}{*}{ FAS } & Forward & 5'-TCC TGC AAC GAG AAC ACG ATC T-3' & NM_007988 \\
\hline & Reverse & 5'-GAG ACG TGT CAC TCC TGG ACT TG-3' & \\
\hline \multirow[t]{2}{*}{$\mathrm{TNF} \alpha$} & Forward & 5'-TCC AGG CGG TGC CTA TGT-3' & NM_001278601 \\
\hline & Reverse & 5'-GCC CCT GCC ACA AGC A-3' & \\
\hline \multirow[t]{2}{*}{$\operatorname{COX}-2$} & Forward & 5'-AGT GGC AAA GGC CTC CAT T-3' & NM_011198 \\
\hline & Reverse & 5'-GCG TTT GCG GTA CTC ATT A-3' & \\
\hline \multirow[t]{2}{*}{ NOS-2 } & Forward & 5'-GCA AAC CCA AGG TCT ACG TTC A-3' & NM_010927 \\
\hline & Reverse & $5^{\prime}$-GAG CAC GCT GAG TAC CTC ATT G-3' & \\
\hline \multirow[t]{2}{*}{$\mathrm{NF}-\kappa \mathrm{B}$} & Forward & 5'-GCC AGC TTC CGT GTT TGT TC-3' & NM_008689 \\
\hline & Reverse & 5'-AGG GTT TCG GTT CAC TAG TTT CC-3' & \\
\hline \multirow[t]{2}{*}{ MCP-1 } & Forward & $5^{\prime}$-GTC TGT GCT GAC CCC AAG AAG-3' & NM_011333 \\
\hline & Reverse & 5'-TGG TTC CGA TCC AGG TTT TTA-3' & \\
\hline
\end{tabular}

RPS17, ribosomal protein S17; ATGL, adipose triglyceride lipase; HSL, hormone-sensitive lipase; LPL, lipoprotein lipase; $\operatorname{PPAR} \gamma$, peroxisome proliferator-activated receptor gamma; PPAR $\delta$, peroxisome proliferator-activated receptor delta; CPT1b, carnitin palmitoyltransferase $1 \mathrm{~b}$; LCAD, long-chain acyl-CoA dehydrogenase; UCP-3, uncoupling protein-3; FAS, fatty acid synthase; TNF $\alpha$, tumor necrosis factor- alpha; COX-2, cyclooxygenase-2; NOS-2, nitric oxide synthase-2; NF- $\kappa \mathrm{B}$, nuclear factor-kappa B; MCP-1, monocyte chemoattractant protein-1. 
Table 3. Effects of enzymatically synthesized glycogen and exercise on the body composition and plasma parameters in high-fat diet-fed mice.

\begin{tabular}{|c|c|c|c|c|c|c|c|}
\hline & Control & ESG & Ex & $\mathrm{ESG}+\mathrm{Ex}$ & ESG & Ex & Interaction \\
\hline Body weight (g) & $41.8 \pm 1.0$ & $40.5 \pm 1.5$ & $38.7 \pm 0.9$ & $37.5 \pm 1.0$ & $p>0.05$ & $p<0.05^{*}$ & $p>0.05$ \\
\hline Food intake $(\mathrm{g})$ & $104.7 \pm 2.6$ & $110.1 \pm 7.1$ & $99.3 \pm 4.4$ & $89.2 \pm 1.5$ & $p>0.05$ & $p<0.05^{*}$ & $p>0.05$ \\
\hline Liver weight (g) & $1.35 \pm 0.04$ & $1.35 \pm 0.04$ & $1.35 \pm 0.04$ & $1.30 \pm 0.04$ & $p>0.05$ & $p>0.05$ & $p>0.05$ \\
\hline Gastrocnemius muscle weight (g) & $0.14 \pm 0.01$ & $0.16 \pm 0.01$ & $0.15 \pm 0.01$ & $0.15 \pm 0.01$ & $p>0.05$ & $p>0.05$ & $p>0.05$ \\
\hline Epididymal adipose tissue weight (g) & $2.23 \pm 0.22$ & $1.77 \pm 0.21$ & $1.56 \pm 0.22$ & $1.11 \pm 0.09$ & $p<0.05^{*}$ & $p<0.05^{*}$ & $p>0.05$ \\
\hline Perirenal adipose tissue weight $(\mathrm{g})$ & $0.63 \pm 0.06$ & $0.48 \pm 0.05$ & $0.44 \pm 0.09$ & $0.32 \pm 0.04$ & $p<0.05^{*}$ & $p<0.05^{*}$ & $p>0.05$ \\
\hline Plasma glucose (mg/dL) & $179 \pm 7$ & $171 \pm 7$ & $188 \pm 15$ & $159 \pm 8$ & $p>0.05$ & $p=0.062$ & $p>0.05$ \\
\hline Plasma NEFA $(\mu \mathrm{Eq} / \mathrm{dL})$ & $54.0 \pm 1.3$ & $54.8 \pm 4.0$ & $50.6 \pm 2.2$ & $51.2 \pm 4.0$ & $p>0.05$ & $p>0.05$ & $p>0.05$ \\
\hline Plasma TG (mg/dL) & $69.4 \pm 9.2^{\mathrm{ab}}$ & $81.1 \pm 9.6^{\mathrm{ab}}$ & $86.0 \pm 7.2^{\mathrm{a}}$ & $58.8 \pm 7.4^{\mathrm{b}}$ & $p>0.05$ & $p>0.05$ & $p<0.05^{*}$ \\
\hline
\end{tabular}

Values are means \pm SE of seven mice in each group. Groups with different letters are significantly different $(p<0.05)$.

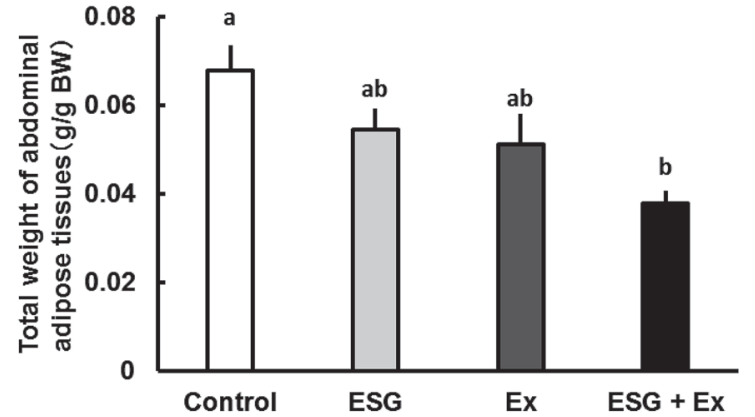

Fig. 1. Effects of enzymatically synthesized glycogen and exercise on the total weights of abdominal adipose tissues (the epididymal and perirenal adipose tissues) in high-fat diet-fed mice. Values are means \pm SE of seven mice in each group. Groups with different letters are significantly different $(p<0.01)$.

were housed individually in plastic cages in at $25^{\circ} \mathrm{C}$ in a room with an automatically controlled $12 \mathrm{~h}$ light : dark cycle (lights on from 0900 to 2100). Upon arrival, the mice were fed a nonpurified diet (MF, 23.1\% crude protein and 3,590 kcal/kg, Oriental Yeast Co., Ltd., Tokyo, Japan) and acclimated to the facility for $5 \mathrm{~d}$ before feeding on the experimental diets. The mice had free access to water and assigned diets throughout the experimental period. Feed intake was measured twice a week. Body weight was measured every week. The animal experiment in the present study was approved by the Institutional Animal Care and Use Committee (Permission number: 27-05-01) and carried out according to the Kobe University Animal Experimentation Regulations.

Experimental design. Twenty-eight male ICR mice were weighed and assigned to four groups $(n=7)$ : a control group (Control); an ESG group (ESG); an exercisetrained group (Ex); and an exercise-trained, ESG group $(\mathrm{ESG}+\mathrm{Ex})$. Average body weight was evenly distributed among the groups. The composition of experimental diets is shown in Table 1. ESG was obtained from Ezaki Glico Co., Ltd. (Osaka, Japan). We adopted the exercise protocol described in previous studies $(22,23)$. Mice in the exercise-trained groups were run on a 2-lane motor- ized rodent treadmill (Melquest Ltd., Toyama, Japan). Mice in the Ex group and ESG+Ex group were trained to run at $25 \mathrm{~m} / \mathrm{min}$ following a 5 -d training program: at $5 \mathrm{~m} / \mathrm{min}$ for $10 \mathrm{~min}, 10 \mathrm{~m} / \mathrm{min}$ for $10 \mathrm{~min}, 15 \mathrm{~m} / \mathrm{min}$ for $10 \mathrm{~min}$ on the first day; at $10 \mathrm{~m} / \mathrm{min}$ for $10 \mathrm{~min}$, $15 \mathrm{~m} / \mathrm{min}$ for $10 \mathrm{~min}, 20 \mathrm{~m} / \mathrm{min}$ for $10 \mathrm{~min}$ on the second day; at $15 \mathrm{~m} / \mathrm{min}$ for $10 \mathrm{~min}, 20 \mathrm{~m} / \mathrm{min}$ for $10 \mathrm{~min}$, $25 \mathrm{~m} / \mathrm{min}$ for $10 \mathrm{~min}$ on the third and fourth days; at $15 \mathrm{~m} / \mathrm{min}$ for $5 \mathrm{~min}, 20 \mathrm{~m} / \mathrm{min}$ for $5 \mathrm{~min}, 25 \mathrm{~m} / \mathrm{min}$ for $20 \mathrm{~min}$ on the fifth day. After the training program, mice in the two exercised-trained groups were run $3 \mathrm{~d} /$ wk on a treadmill at $25 \mathrm{~m} / \mathrm{min}$ for $30 \mathrm{~min}$ for $3 \mathrm{wk}$.

At the end of the experimental period mice were anesthetized by the inhalation of isoflurane (Wako Pure Chemical Industries, Ltd., Osaka, Japan) after $24 \mathrm{~h}$ of fasting, and their blood was collected from the abdominal vein. EDTANa 2 was used as an anticoagulant at a concentration of $1 \mathrm{mg} / \mathrm{mL}$ blood. Plasma was immediately separated by centrifugation at $3,000 \times g$ for $10 \mathrm{~min}$ at $4^{\circ} \mathrm{C}$. It was then frozen using liquid nitrogen and stored at $-80^{\circ} \mathrm{C}$ for plasma component analysis. The liver, epididymal adipose tissues, perirenal adipose tissues, and gastrocnemius muscles were excised and weighed. The epididymal adipose tissues and gastrocnemius muscles were then immediately frozen in liquid nitrogen for storage at $-80^{\circ} \mathrm{C}$ before real-time PCR analysis.

Plasma components analysis. Plasma levels of glucose, nonesterified fatty acid (NEFA), and triglyceride (TG) were measured by colorimetric enzymatic methods using commercial kits (LabAssay ${ }^{\mathrm{TM}}$ Glucose, LabAssay $^{\mathrm{TM}}$ NEFA, and LabAssay ${ }^{\mathrm{TM}}$ Triglyceride, respectively, Wako Pure Chemical Industries, Ltd.).

Real time-PCR analysis. Total RNA was extracted from the epididymal adipose tissue and gastrocnemius muscle using Sepazol ${ }^{\circledR}$-RNA I (Nacalai Tesque, Inc., Kyoto, Japan). First-strand complementary DNA (cDNA) was synthesized from total RNA using ReverTra Ace ${ }^{\circledR}$ qPCR RT Master Mix with gDNA Remover (Toyobo Co., Ltd., Osaka, Japan). The cDNAs were amplified with primers described in Table 2. SYBR ${ }^{\circledR}$ Premix Ex Taq ${ }^{\mathrm{TM}}$ II (Tli RnaseH Plus) was purchased from Takara-bio Co., Ltd. (Shiga, Japan), and mRNA levels were quantified in duplicate using the Applied Biosystems 7300 Real- 
Table 4. Effects of enzymatically synthesized glycogen and exercise on the mRNA levels of genes related to lipid metabolism- and inflamation-related genes in high-fat diet-fed mice.

\begin{tabular}{|c|c|c|c|c|c|c|c|}
\hline & Control & ESG & Ex & $\mathrm{ESG}+\mathrm{Ex}$ & ESG & Ex & Interaction \\
\hline ATGL & $56.6 \pm 13.1$ & $66.1 \pm 15.3$ & $63.1 \pm 19.8$ & $49.5 \pm 13.2$ & $p>0.05$ & $p>0.05$ & $p>0.05$ \\
\hline HSL & $27.7 \pm 5.40$ & $37.8 \pm 6.28$ & $46.5 \pm 16.7$ & $39.0 \pm 10.8$ & $p>0.05$ & $p>0.05$ & $p>0.05$ \\
\hline LPL & $148 \pm 36.7$ & $157 \pm 36.3$ & $152 \pm 50.4$ & $124 \pm 31.8$ & $p>0.05$ & $p>0.05$ & $p>0.05$ \\
\hline $\operatorname{PPAR} \gamma$ & $1.59 \pm 0.32$ & $2.02 \pm 0.31$ & $1.92 \pm 0.69$ & $1.87 \pm 0.55$ & $p>0.05$ & $p>0.05$ & $p>0.05$ \\
\hline FAS & $0.51 \pm 0.13$ & $0.55 \pm 0.18$ & $0.68 \pm 0.23$ & $0.31 \pm 0.04$ & $p>0.05$ & $p>0.05$ & $p>0.05$ \\
\hline $\operatorname{TNF} \alpha$ & $0.31 \pm 0.08$ & $0.20 \pm 0.04$ & $0.22 \pm 0.12$ & $0.18 \pm 0.05$ & $p>0.05$ & $p>0.05$ & $p>0.05$ \\
\hline $\mathrm{COX}-2$ & $0.37 \pm 0.29$ & $2.53 \pm 1.36$ & $15.9 \pm 11.1$ & $19.4 \pm 18.6$ & $p>0.05$ & $p>0.05$ & $p>0.05$ \\
\hline $\mathrm{NF}-\kappa \mathrm{B}$ & $1.00 \pm 0.18$ & $1.02 \pm 0.14$ & $1.33 \pm 0.32$ & $1.44 \pm 0.33$ & $p>0.05$ & $p>0.05$ & $p>0.05$ \\
\hline NOS-2 & $0.76 \pm 0.16$ & $0.87 \pm 0.28$ & $0.94 \pm 0.31$ & $0.50 \pm 0.14$ & $p>0.05$ & $p>0.05$ & $p>0.05$ \\
\hline MCP-1 & $0.22 \pm 0.11$ & $0.11 \pm 0.02$ & $0.07 \pm 0.02$ & $0.07 \pm 0.03$ & $p>0.05$ & $p>0.05$ & $p>0.05$ \\
\hline
\end{tabular}

Values are means \pm SEM of seven mice in each group.

Time PCR system (Applied Biosystems, Foster City, CA) according to the supplier's recommendations.

Statistical analysis. Data were analyzed by a twoway ANOVA with the main effects of dietary ESG (ESG) and exercise (Ex). The Bonferroni/Dunn test was also performed to evaluate the significant interaction in plasma TG and the additive effect of ESG and exercise on the weights of abdominal adipose tissues. All statistical analyses were performed using a commercial software package (StatView version 5, SAS Institute, Cary, NC, 1998). Differences with $p<0.05$ were considered significant.

\section{RESULTS}

ESG significantly decreased the weights of the epididymal and perirenal adipose tissues (Table 3). Exercise significantly decreased body weight, total food intake, and the weights of the epididymal and perirenal adipose tissues (Table 3). In addition, the combination of ESG and exercise significantly decreased the total weight of the epididymal and perirenal adipose tissues (Fig. 1, Total weight of abdominal adipose tissues).

Neither ESG nor exercise significantly altered the weights of the liver or gastrocnemius muscle (Table 3). Since the weights of abdominal adipose tissues were decreased by exercise (Table 3), the decreased body weight may be due to the suppression of body fat accumulation. These results suggest that ESG and exercise have a suppressive effect on abdominal fat accumulation, and in combination showed an additive effect in HFD-fed mice.

We next examined the effects of ESG and exercise on plasma components and found that the plasma TG level in the ESG+Ex group was significantly lower than that in the Ex group, whereas the levels of plasma glucose and NEFA were not significantly changed by ESG or exercise (Table 3 ).

We further examined the mRNA levels of lipolytic genes (ATGL and HSL), lipogenic genes (PPAR $\gamma$, FAS, and LPL), pro-inflammatory cytokines (TNF $\alpha$ and MCP-1), pro-inflammatory enzymes (COX-2 and NOS-2), and the transcriptional factor of pro-inflammatory genes (NF- $\kappa \mathrm{B})$ in the epididymal adipose tissue. However, there was no significant difference in the mRNA levels of any of these genes (Table 4). It is therefore likely that the suppression of abdominal fat accumulation observed in this study was not related to the expression of these genes in the adipose tissue.

The gastrocnemius muscle-tendon unit is central to human locomotion (24). In addition, a number of studies suggest that exercise stimulates fatty acid oxidation in the gastrocnemius muscle of mice $(16,25-28)$. Therefore, we finally examined the effects of ESG and exercise on the mRNA levels of lipid metabolism-related genes in the gastrocnemius muscle in HFD-fed mice (Fig. 2). ESG significantly decreased the mRNA level of ATGL. PPAR $\delta$, the transcriptional factor of fatty acid oxidation-related genes, was significantly decreased by ESG at the mRNA level. In addition, the mRNA levels of LCAD tended to be decreased by ESG. These results suggest that ESG may suppress fat utilization in the skeletal muscle. In contrast, exercise significantly increased the mRNA levels of ATGL, PPAR $\delta$, and the target genes of PPAR $\delta$ such as CPT1b and UCP-3. In addition, LPL, which plays a critical role in FFA uptake from plasma TG, was increased at the mRNA level. These results suggest that exercise may induce fat utilization in the skeletal muscle. Taken together, ESG and exercise may differently influence lipid metabolism in the skeletal muscle.

\section{DISCUSSION}

As shown in Fig. 1, the combination of ESG and exercise significantly reduced the total weight of abdominal adipose tissues. On the other hand, ESG and exercise had opposite effects on the mRNA levels of lipid-metabolism-related genes in the gastrocnemius muscle (Fig. 2 ). These results suggest that ESG and exercise may suppress abdominal fat accumulation by different mechanisms. There is evidence that dietary ESG significantly increased the amount of lipid in the feces of rats (16). We also confirmed that oral administration of ESG with olive oil significantly suppressed the postprandial elevation of plasma TG in mice (unpublished data). Therefore, ESG may contribute to the reduction of energy 

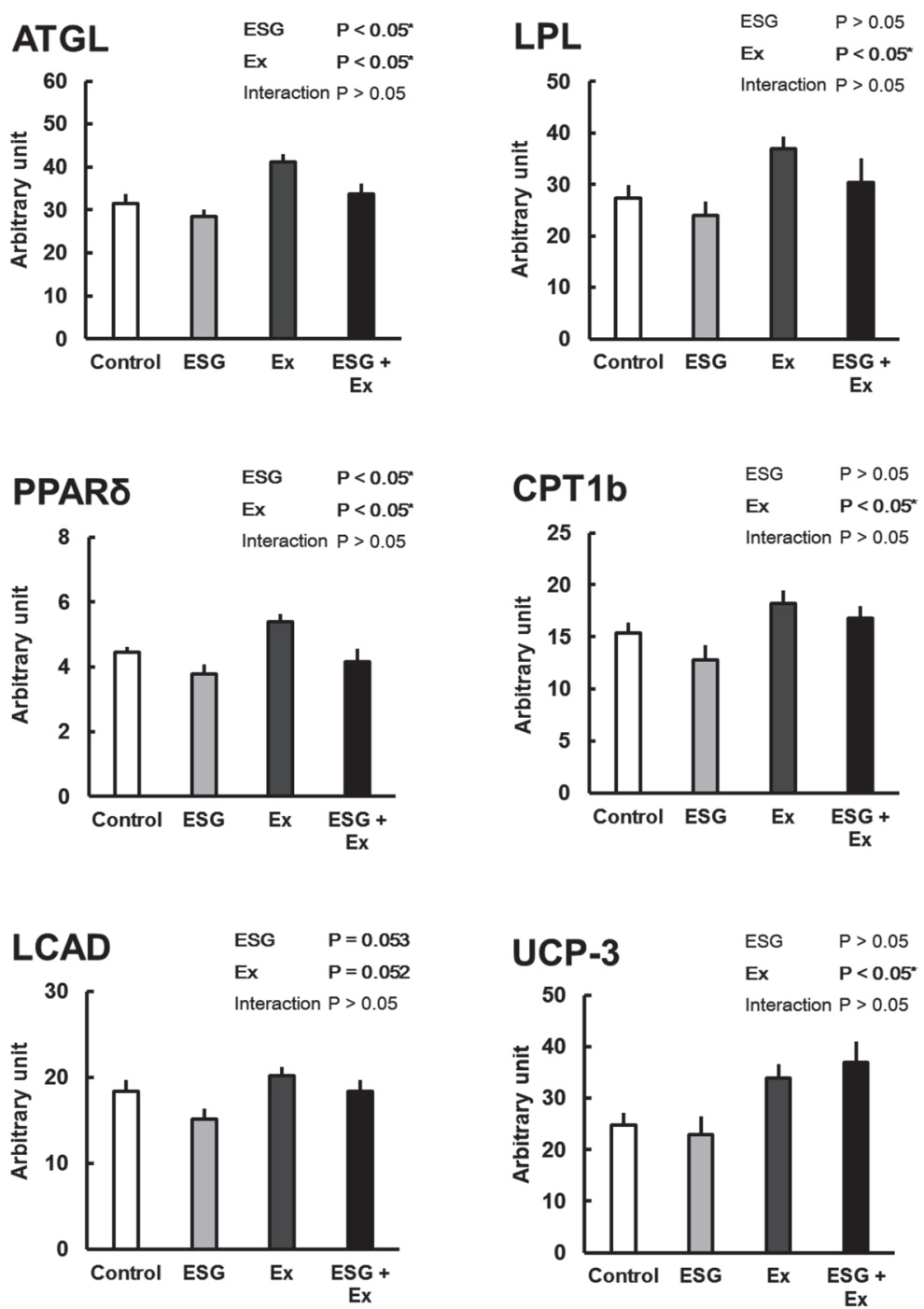

Fig. 2. Effects of enzymatically synthesized glycogen and exercise on the mRNA levels of lipid metabolism-related genes in the gastrocnemius muscle in high-fat diet-fed mice. Values are means \pm SE of seven mice in each group.

intake (EI) by the suppression of TG absorption from the gastrointestinal tract. The detailed mechanism of the interaction between ESG and exercise is not clear. For example, the effects of exercise on the mRNA levels of ATGL, CPT1b, and LCAD seem to be attenuated by dietary ESG (Fig. 2, Ex group versus ESG+Ex group, 82-92\%). However, the mRNA levels of these enzymes in the ESG+Ex group were still higher than those in the ESG group (Fig. 2, ESG group versus ESG+Ex group, $118-132 \%)$. It is therefore possible that the effects of ESG and exercise are additive. Thus, the combination of dietary ESG and exercise may be possible as an efficient approach to prevent or ameliorate obesity. Further study is needed to clarify the effects of ESG and exercise on the amount of lipid in the feces and fatty acid utilization in the skeletal muscles.

The addition of ESG in the HFD significantly decreased the weights of abdominal adipose tissues (Table 3) and the mRNA levels of ATGL and PPAR $\delta$ in the gastrocnemius muscle (Fig. 2). When EI is saved, energy expenditure also declines to the same level as EI to adjust the energy balance (29-31). ESG may contribute to the reduction of EI by the suppression of TG absorption from the gastrointestinal tract as described above. It is therefore likely that the reduction in fat intake by ESG may suppress energy expenditure, which in turn results in decreased mRNA levels of fatty acid oxidation-related genes in the skeletal muscle.

In the present study, we have analyzed the mRNA levels of lipid metabolism-related genes in the skeletal muscle. However, it is well known that enzymatic activity can be post-translationally regulated. For example, the enzymatic activity of CPT1 is well known to be suppressed by malonyl-CoA, and a recent transgenic study showed that decreased CPT1 sensitivity to malonyl-CoA inhibition in isolated muscle mitochondria increases muscle mitochondrial fatty acid oxidation capacity ex vivo and whole body fatty acid utilization in vivo (32). Further study is needed to clarify the effects of exercise on the enzymatic activity of lipid metabolism-related enzymes in the skeletal muscle.

Exercise significantly decreased food intake and body weight (Table 3). A brief suppression of appetite after exercise, termed exercise-induced anorexia, has been 
reported, although the detailed mechanism is unknown (33-36). For example, 3-d voluntary wheel running significantly decreased daily food intake in rats (33). This phenomenon only occurs during, and for a short time following, vigorous exercise $\left(>60 \%\right.$ maximum $\mathrm{O}_{2}$ consumption) (37). The treadmill running exercise $(25 \mathrm{~m} /$ min for $30 \mathrm{~min}$ ) may be characterized as low to moderate intensity because mice can run for more than $3 \mathrm{~h}$ at this running speed. However, it is possible that the decreased food intake is related to the decreased body weight in exercised mice.

It is not clear why the plasma TG level in the ESG+Ex group was the lowest among the groups (Table 3 ). Since the blood was collected after $24 \mathrm{~h}$ of fasting, most of the plasma VLDL- or LDL-TG is attributed to endogenous TGs. Plasma NEFAs released from abdominal adipose tissue are reconstituted to VLDL-TGs in the liver during fasting (38). In the present study, ESG+Ex mice showed the lowest weights for abdominal adipose tissues (Table 3). In addition, the mRNA level of ATGL, one of the rate-limiting enzymes of lipolytic, in the epididymal adipose tissue was also the lowest in the ESG+Ex group. Therefore, it is possible that the lowest plasma TG level in the ESG+Ex group is the result of a shortage of NEFA supply from abdominal adipose tissues to the liver.

In conclusion, we evaluated the combination effect of dietary ESG with exercise on abdominal fat accumulation in HFD-fed mice. Our findings suggest that the combination of ESG and exercise may effectively suppress abdominal fat accumulation by different mechanisms.

\section{Acknowledgments}

This work was supported in part by a Special Coordination Fund for Promoting Science and Technology, Creation of Innovative Centers for Research Areas (Innovative Bioproduction Kobe) from the Ministry of Education, Culture, Sports, Science and Technology (MEXT).

\section{REFERENCES}

1) Prospective Studies Collaboration, Whitlock G, Lewington S, Sherliker P, Clarke R, Emberson J, Halsey J, Qizilbash N, Collins R, Peto R. 2009. Body-mass index and cause-specific mortality in 900000 adults: collaborative analyses of 57 prospective studies. Lancet $\mathbf{3 7 3}$ : 1083-1096.

2) Abdullah A, Peeters A, de Courten M, Stoelwinder J. 2010. The magnitude of association between overweight and obesity and the risk of diabetes: a meta-analysis of prospective cohort studies. Diabetes Res Clin Pract 89: 309-319.

3) Finucane MM, Stevens GA, Cowan MJ, Danaei G, Lin JK, Paciorek CJ, Singh GM, Gutierrez HR, Lu Y, Bahalim AN, Farzadfar F, Riley LM, Ezzati M. 2011. National, regional, and global trends in body-mass index since 1980: systematic analysis of health examination surveys and epidemiological studies with 960 country-years and 9.1 million participants. Lancet 377: 557-567.

4) Stevens GA, Singh GM, Lu Y, Danaei G, Lin JK, Finucane MM, Bahalim AN, McIntire RK, Gutierrez HR, Cowan M, Paciorek CJ, Farzadfar F, Riley L, Ezzati M. 2012. National, regional, and global trends in adult overweight and obesity prevalences. Popul Health Metr 10: 22.

5) $\mathrm{Ng} \mathrm{M}$, Fleming T, Robinson M, Thomson B, Graetz N, Margono C, Mullany EC, Biryukov S, Abbafati C, Abera SF, Abraham JP, Abu-Rmeileh NM, Achoki T, AlBuhairan FS, Alemu ZA, Alfonso R, Ali MK, Ali R, Guzman NA, Ammar W, Anwari P, Banerjee A, Barquera S, Basu S, Bennett DA, Bhutta Z, Blore J, Cabral N, Nonato IC, Chang JC, Chowdhury R, Courville KJ, Criqui MH, Cundiff DK, Dabhadkar KC, Dandona L, Davis A, Dayama A, Dharmaratne SD, Ding EL, Durrani AM, Esteghamati A, Farzadfar F, Fay DF, Feigin VL, Flaxman A, Forouzanfar MH, Goto A, Green MA, Gupta R, Hafezi-Nejad N, Hankey GJ, Harewood HC, Havmoeller R, Hay S, Hernandez L, Husseini A, Idrisov BT, Ikeda N, Islami F, Jahangir E, Jassal SK, Jee SH, Jeffreys M, Jonas JB, Kabagambe EK, Khalifa SE, Kengne AP, Khader YS, Khang YH, Kim D, Kimokoti RW, Kinge JM, Kokubo Y, Kosen S, Kwan G, Lai T, Leinsalu M, Li Y, Liang X, Liu S, Logroscino G, Lotufo PA, Lu Y, Ma J, Mainoo NK, Mensah GA, Merriman TR, Mokdad AH, Moschandreas J, Naghavi M, Naheed A, Nand D, Narayan KM, Nelson EL, Neuhouser ML, Nisar MI, Ohkubo T, Oti SO, Pedroza A, Prabhakaran D, Roy N, Sampson U, Seo H, Sepanlou SG, Shibuya K, Shiri R, Shiue I, Singh GM, Singh JA, Skirbekk V, Stapelberg NJ, Sturua L, Sykes BL, Tobias M, Tran BX, Trasande L, Toyoshima H, van de Vijver S, Vasankari TJ, Veerman JL, Velasquez-Melendez G, Vlassov VV, Vollset SE, Vos T, Wang C, Wang X, Weiderpass E, Werdecker A, Wright JL, Yang YC, Yatsuya H, Yoon J, Yoon SJ, Zhao Y, Zhou M, Zhu S, Lopez AD, Murray CJ, Gakidou E. 2013. Global, regional, and national prevalence of overweight and obesity in children and adults during 1980-2013: a systematic analysis for the Global Burden of Disease Study. Lancet 384: 766-781.

6) Grundy SM. 2007. Metabolic syndrome: a multiplex cardiovascular risk factor. J Clin Endocrinol Metab 92: 399-404.

7) Pou KM, Massaro JM, Hoffmann U, Lieb K, Vasan RS, O'Donnell CJ, Fox CS. 2009. Patterns of abdominal fat distribution: the Framingham Heart Study. Diabetes Care 32: 481-485.

8) Fox CS, Massaro JM, Hoffmann U, Pou KM, Maurovich-Horvat P, Liu CY, Vasan RS, Murabito JM, Meigs JB, Cupples LA, D'Agostino RB Sr, O’Donnell CJ. 2007. Abdominal visceral and subcutaneous adipose tissue compartments: association with metabolic risk factors in the Framingham Heart Study. Circulation 116: 39-48.

9) Sahakyan KR, Somers VK, Rodriguez-Escudero JP, Hodge DO, Carter RE, Sochor O, Coutinho T, Jensen MD, Roger VL, Singh P, Lopez-Jimenez F. 2015. Normal-weight central obesity: Implications for total and cardiovascular mortality. Ann Intern Med 163: 827-835.

10) Duca FA, Yue JT. 2014. Fatty acid sensing in the gut and the hypothalamus: in vivo and in vitro perspectives. Mol Cell Endocrinol 397: 23-33.

11) Kajiura H, Kakutani R, Akiyama T, Takata H, Kuriki T. 2008. A novel enzymatic process for glycogen production. Biocatal Biotransform 26: 133-140.

12) Takata H, Kajiura H, Furuyashiki T, Kakutani R, Kuriki T. 2009. Fine structural properties of natural and synthetic glycogens. Carbohydr Res 344: 654-659.

13) Kajiura H, Takata H, Kuriki T, Kitamura S. 2010. Structure and solution properties of enzymatically synthesized glycogen. Carbohydr Res 345: 817-824. 
14) Kakutani R, Adachi Y, Kajiura H, Takata H, Kuriki T, Ohno N. 2007. Relationship between structure and immunostimulating activity of enzymatically synthesized glycogen. Carbohydr Res 342: 2371-2379.

15) Furuyashiki T, Takata H, Kojima I, Kuriki T, Fukuda I, Ashida H. 2011. Metabolic fate of orally administered enzymatically synthesized glycogen in rats. Food Funct $\mathbf{2}$ : 183-189.

16) Furuyashiki T, Ogawa R, Nakayama $Y$, Honda K, Kamisoyama H, Takata H, Yasuda M, Kuriki T, Ashida H. 2013. Enzymatically synthesized glycogen reduces lipid accumulation in diet-induced obese rats. Nutr Res 33: $743-752$.

17) Trautwein EA, Rieckhoff D, Erbersdobler HF. 1998. Dietary inulin lowers plasma cholesterol and triacylglycerol and alters biliary bile acid profile in hamsters. J Nutr 128: 1937-1943.

18) Kay RM, Truswell AS. 1977. Effect of citrus pectin on blood lipids and fecal steroid excretion in man. Am J Clin Nutr 30: 171-175.

19) Donnelly JE, Blair SN, Jakicic JM, Manore MM, Rankin JW, Smith BK. 2009. Appropriate physical activity intervention strategies for weight loss and prevention of weight regain for adults. Med Sci Sports Exerc 41: 459-471.

20) Miller CT, Fraser SF, Levinger I, Straznicky NE, Dixon JB, Reynolds J, Selig SE. 2013. The effects of exercise training in addition to energy restriction on functional capacities and body composition in obese adults during weight loss: a systematic review. PLoS One 8: e81692.

21) Schwingshackl L, Dias S, Hoffmann G. 2014. Impact of long-term lifestyle programmes on weight loss and cardiovascular risk factors in overweight/obese participants: a systematic review and network meta-analysis. Syst Rev 3: 130.

22) Shimotoyodome A, Haramizu S, Inaba M, Murase T, Tokimitsu I. 2005. Exercise and green tea extract stimulate fat oxidation and prevent obesity in mice. Med Sci Sports Exerc 37: 1884-1892.

23) Katsumura M, Takagi S, Oya H, Tamura S, Saneyasu T, Honda K, Kamisoyama H. 2016. Effects of dietary heme iron and exercise training on abdominal fat accumulation and lipid metabolism in high-fat diet-fed mice. Anim Sci J. doi: 10.1111/asj.12734.

24) Butler EE, Dominy NJ. 2016. Architecture and functional ecology of the human gastrocnemius muscle-tendon unit. J Anat 228: 561-568.

25) Ohyama K, Nogusa Y, Suzuki K, Shinoda K, Kajimura S, Bannai M. 2015. A combination of exercise and capsinoid supplementation additively suppresses dietinduced obesity by increasing energy expenditure in mice. Am J Physiol Endocrinol Metab 308: E315-E323.

26) Kim JH, Pan JH, Lee ES, Kim YJ. 2015. L-Carnitine enhances exercise endurance capacity by promoting muscle oxidative metabolism in mice. Biochem Biophys Res Commun 464: 568-573.

27) Aoi W, Naito Y, Takanami Y, Ishii T, Kawai Y, Akagiri S, Kato Y, Osawa T, Yoshikawa T. 2008. Astaxanthin improves muscle lipid metabolism in exercise via inhibitory effect of oxidative CPT I modification. Biochem Biophys Res Commun 366: 892-897.

28) Ringseis R, Mooren FC, Keller J, Couturier A, Wen G, Hirche F, Stangl GI, Eder K, Krüger K. 2011. Regular endurance exercise improves the diminished hepatic carnitine status in mice fed a high-fat diet. Mol Nutr Food Res 55: S193-S202.

29) MacLean PS, Higgins JA, Jackman MR, Johnson GC, Fleming-Elder BK, Wyatt HR, Melanson EL, Hill JO. 2006. Peripheral metabolic responses to prolonged weight reduction that promote rapid, efficient regain in obesity-prone rats. Am J Physiol Regul Integr Comp Physiol 290: R1577-R1588.

30) MacLean PS, Higgins JA, Johnson GC, Fleming-Elder BK, Donahoo WT, Melanson EL, Hill JO. 2004. Enhanced metabolic efficiency contributes to weight regain after weight loss in obesity-prone rats. Am J Physiol Regul Integr Comp Physiol 287: R1306-R1315.

31) Ishii S, Osaki N, Shimotoyodome A. 2016. The effects of a hypocaloric diet on diet-induced thermogenesis and blood hormone response in healthy male adults: a pilot study. J Nutr Sci Vitaminol 62: 40-46.

32) Vavrova E, Lenoir V, Alves-Guerra MC, Denis RG, Castel J, Esnous C, Dyck JR, Luquet S, Metzger D, Bouillaud F, Prip-Buus C. 2016. Muscle expression of a malonylCoA-insensitive carnitine palmitoyltransferase-1 protects mice against high-fat/high-sucrose diet-induced insulin resistance. Am J Physiol Endocrinol Metab 311: E649-E660.

33) Zheng F, Kim YJ, Moran TH, Li H, Bi S. 2016. Central transthyretin acts to decrease food intake and body weight. Sci Rep 6: 24238.

34) King NA, Tremblay A, Blundell JE. 1997. Effects of exercise on appetite control: implications for energy balance. Med Sci Sports Exerc 29: 1076-1089.

35) Martins C, Morgan LM, Bloom SR, Robertson MD. 2007. Effects of exercise on gut peptides, energy intake and appetite. J Endocrinol 193: 251-258.

36) Ueda SY, Yoshikawa T, Katsura Y, Usui T, Nakao H, Fujimoto S. 2009. Changes in gut hormone levels and negative energy balance during aerobic exercise in obese young males. J Endocrinol 201: 151-159.

37) Blundell JE, Stubbs RJ, Hughes DA, Whybrow S, King NA. 2003. Cross talk between physical activity and appetite control: does physical activity stimulate appetite? Proc Nutr Soc 62: 651-661.

38) Havel RJ, Kane JP. 1975. Quantification of triglyceride transport in blood plasma: a critical analysis. Fed Proc. 34: $2250-2257$. 